\title{
PERLINDUNGAN PENGGUNA KE ATAS SKIM PELANCONGAN DI MALAYSIA
}

\section{Consumer Protection on Tourism Scheme in Malaysia}

\author{
Siti Aisyah Samudin \\ PhD Candidate, Department of Shariah and Law, \\ Academy of Islamic Studies, \\ University of Malaya, 50603 Kuala Lumpur. \\ aisy_awani@um.edu.my \\ Zalina Zakaria \\ Lecturer, Department of Shariah and Law, \\ Academy of Islamic Studies, \\ University of Malaya, 50603 Kuala Lumpur. \\ zalina_jsu@um.edu.my
}

\begin{abstract}
Tourist Scheme is a holiday plan and travel provided by any travel agencies registered under the Ministry of Tourism and Ministry of Finance in Malaysia. Usually, it offers vacation packages include low cost of fee, tour guide service, low-cost accommodation and other services as an attraction to their customers or users. This study aimed to analyze the setup of the extent to which the relevant laws tourism scheme to protect the rights of consumers in Malaysia. The main method in carrying out this study is the analysis of documents and interview conducted with Mr. Mohammad Nordin Ab. Rauf as a Vice President of Tribunal for Consumer Claims Malaysia (TTPM). The findings show that existing law is adequate and able to protect consumers from fraudulent schemes tourism, as the legal provisions are there to prosecute the parties who breach the contract thus protecting the consumers.
\end{abstract}

Keywords: tourism scheme, services, remedies, award 


\section{PENDAHULUAN}

Industri pelancongan dan hospitaliti telah diiktiraf sebagai antara faktor utama yang menyumbang kepada pertumbuhan ekonomi negara (Ahmad Afiq Hasan \& Nuraisyah Chua Abdullah, 2012: 1). Kemunculan agensi-agensi pelancongan dari sektor kerajaan dan swasta dengan memperkenalkan skimskim pelancongan mereka turut berhasil dalam menarik minat para pengguna di Malaysia.

Statistik yang dikeluarkan oleh Jabatan Perangkaan Malaysia menunjukkan jumlah pelancong dalam dan luar negara telah mencatatkan peningkatan sejak tahun 2010 sehingga tahun 2015. Seramai 176.9 juta pelawat telah direkodkan pada 2015 dengan peningkatan sebanyak 4.5 peratus berbanding tahun 2014 . Manakala, bilangan perjalanan meningkat 8.1 peratus iaitu daripada 217.5 juta perjalanan pada 2014 kepada 235.2 juta perjalanan pada 2015 . $^{1}$

Namun, dalam keghairahan agensi-agensi ini menarik pengguna untuk turut serta dalam perkhidmatan mereka, seringkali berlakunya perlanggaran hakhak kepenggunaan sebagaimana yang telah digariskan oleh undang-undang di Malaysia. ${ }^{2}$ Tambahan pula, sejak lima tahun kebelakangan ini, iaitu dari tahun 2010 hingga kini, negara sering digemparkan dengan hal penyelewengan dan penipuan oleh agensi-agensi pelancongan melalui skim pelancongan yang diperkenalkan oleh pihak mereka.

Statistik dan analisis jumlah penipuan skim pelancongan yang telah dikeluarkan oleh beberapa kementerian dalam kerajaan seperti Kementerian Perdagangan Dalam Negeri, Koperasi dan Kepenggunaan (KPDNKK), Kementerian Pelancongan dan Kebudayaan Malaysia dan Pusat Khidmat Aduan Pengguna Nasional (NCCC) membuktikan wujudnya pencabulan hak ke atas pengguna berdasarkan aduan dan saman yang dibuat oleh orang ramai. ${ }^{3}$

Statistik rasmi yang telah dikeluarkan oleh KPDNKK berkenaan penipuan dalam skim pelancongan khusus melibatkan umrah dan ziarah pada tahun 2011

1 Jabatan Perangkaan Malaysia, "Penyiasatan Pelancongan Domestik Malaysia", Laman Sesawang Jabatan Perangkaan Malaysia, https://www.dosm.gov.my/v1/ index.php?r, dicapai 11 Mac 2015.

2 Kementerian Perdagangan Dalam Negeri, Koperasi dan Kepenggunaan, "Tribunal Tuntutan Pengguna Malaysia", Laman Sesawang Kementerian Perdagangan Dalam Negeri, Koperasi dan Kepenggunaan Online, https://ttpm.kpdnkk.gov.my/portal/ index.php/my/, dicapai 26 Mei 2015.

3 Pusat Khidmat Aduan Pengguna Nasional, "Info Pengguna- Time Share/Kongsi Masa”, Laman Sesawang Sinar Pusat Khidmat Aduan Pengguna Nasional Online, http://www.nccc.org.my/v2/index.php/time-share, dicapai 11 Mac 2015. 
adalah sebanyak $527 \mathrm{kes},{ }^{4} 2012$ pula mencatatkan 303 kes (Ibid) dan 2013 pula adalah sebanyak 761 kes (Ibid). Walaupun terdapat penurunan pada jumlah kes bagi tahun 2011 dan 2012, namun bilangan kes yang diadukan kepada Tribunal Tuntutan Pengguna Malaysia bagi tahun berikutnya telah meningkat dengan mendadak iaitu dengan pertambahan sebanyak 234 kes. Pertambahan kes yang diadukan ini menyebabkan bertambahnya kerugian yang terpaksa ditanggung oleh pengguna yang terjebak dengan penipuan skim pelancongan yang ditawarkan oleh agensi-agensi pelancongan ini (Ibid).

Sebagai contoh, sebanyak sembilan kes penipuan umrah melibatkan kerugian kira-kira RM14.1 juta direkodkan Kementerian Pelancongan dan Kebudayaan sejak 2009 hingga Mei 2013. ${ }^{5}$ Menteri Pelancongan dan Kebudayaan menyatakan bahawa kes itu membabitkan lapan buah syarikat pengendalian pelancongan dan agensi pengembaraan yang berlesen serta sebuah syarikat pengendalian pelancongan yang tidak berlesen. Mengulas lanjut, Mohamed Nazri Abdul Aziz berkata, tindakan yang boleh dikenakan terhadap syarikat pengendalian pelancongan dan agensi pengembaraan yang tidak memberi perkhidmatan mengikut terma dan syarat dipersetujui atau penipuan ialah mereka perlu bayar balik wang dibayar, membayar pampasan, tindakan kompaun atau pembatalan lessen. Mohamed Nazri Abdul Aziz berkata, langkah lain adalah dengan meningkatkan pemantauan dan penguatkuasaan bawah Akta Industri Pelancongan 1992 ke atas syarikat pengendalian pelancongan dan agensi pengembaraan berlesen serta syarikat atau individu yang mengendalikan pakej tanpa lesen.

Proses penyelesaian melibatkan penipuan dalam sektor pelancongan ini pula dibuat dengan merujuk kepada undang-undang bertulis. Rujukan undangundang yang digunakan tidak hanya khusus kepada statut tertentu, sebaliknya terkandung dalam beberapa akta seperti Akta Industri Pelancongan 1992, Akta Kontrak 1950 dan Akta Pelindungan Pengguna 1999. Oleh hal yang demikian, rentetan daripada wujudnya polemik pelanggaran hak ini, satu kajian dan penyelidikan ditil perlu dilaksanakan dalam mengenalpasti undang-undang yang berupaya memelihara hak-hak pengguna serta mampu memberi remedi sebagai gantian atas kerugian yang dialami mereka.

4 Statistik yang dikeluarkan oleh Tribunal Tuntutan Pengguna Malaysia di bawah Kementerian Perdagangan Dalam Negeri, Koperasi, dan Kepenggunaan.

5 Sinar Harian, "9 Kes Tipu Umrah Libat 14.1 Juta”, Laman Sesawang Sinar Harian Online, http://www.sinarharian.com.my/nasional/9-kes-tipu-umrah-libat-rm14-1juta-1.291184, dicapai 7 Mac 2016. 


\section{KONSEP SKIM PELANCONGAN DAN PERLINDUNGAN PENGGUNA}

Skim pelancongan (tourism scheme) ditakrifkan sebagai satu pelan atau rancangan perjalanan dan percutian yang disediakan oleh agensi-agensi pelancongan yang berdaftar di bawah Kementerian Pelancongan Malaysia dan Kementerian Kewangan Malaysia (MOF) (Nuraisyah Chua Abdullah, 2013: 3). Hal ini adalah selaras dengan Akta Tatacara Kewangan 1957 (Akta 61) dan Arahan Perbendaharaan serta Surat Pekeliling Perbendaharaan (SPP) Bil.6 Tahun 2010 yang menghendaki semua syarikat dan agensi yang ingin berurusniaga dengan Kerajaan supaya berdaftar di bawah Kementerian Kewangan Malaysia (MOF) (Ibid).

Berdasarkan definisi ringkas ini, dapat disimpulkan bahawa skim pelancongan merupakan pelan yang lazimnya menawarkan pakej percutian merangkumi tambang murah, khidmat pemandu pelancong, kos penginapan rendah serta menjanjikan pelbagai lagi perkhidmatan menarik sebagai satu daya tarikan kepada pelanggan mereka atau pengguna. Skim pelancongan yang sah dan diperakui adalah satu skim yang dikeluarkan oleh syarikat atau agensi yang berdaftar di bawah MOF (Ibid).

Manakala, pengguna secara umum, membawa maksud individu yang membeli suatu barangan atau perkhidmatan untuk kegunaan diri, rumahtangga atau isi rumah (Birshan Singh, 2014: 2). Menurut Thomas Frank, pengguna adalah individu atau sesiapa sahaja yang menggunakan barang, perkhidmatan atau sumber alam semula jadi untuk memenuhi keperluan dan kehendak masing-masing (Thomas Frank, 1997: 19). Pengguna (consumer) sering dikaitkan dengan istilah kepenggunaan (consumerism) yang bermaksud segala kegiatan yang dilakukan oleh orang ramai untuk menjaga hak dan kepentingan mereka sebagai pengguna (Peter Drucker, 2007: 29).

Skim pelancongan dan percutian pada dasarnya ditetapkan oleh manamana syarikat atau agensi yang terlibat dengan industri pelancongan. ${ }^{6}$ Terdapat beberapa jenis skim pelancongan yang telah dilaksanakan oleh agensi-agensi ini merangkumi Skim Pelancongan Perkongsian Masa dan Skim Pelancongan Bayaran Mudah. Menurut Nurbaiti Abdul Karim, Pegawai Perhubungan di Right TIME Travel Sdn Bhd, skim-skim ini dirangka berdasarkan keuntungan, tarikan pelanggan dan keselesaan mereka.

${ }_{6}$ Nurbaiti Abdul Karim (Pegawai Perhubungan, Right TIME Travel Sdn. Bhd.), dalam temu bual beliau dengan penulis, 23 Mac 2015. 
Beliau mengulas bahawa skim pelancongan yang sah haruslah mengikut peraturan dan undang-undang yang mengikat dan berkaitan dengannya. Selain itu, antara tawaran dan perkhimatan yang dirangka dalam sesebuah skim pelancongan adalah khidmat pemandu pelancong berpengalaman, tambang murah, pembayaran mudah secara ansuran atau berkala serta penginapan mewah (Nuraisyah Chua Abdullah, 2010: 47).

Pada umumnya, terdapat dua kategori skim pelancongan yang diamalkan di Malaysia, iaitu Skim Pelancongan Bayaran Mudah dan Skim Pelancongan Perkongsian Masa.

\section{Skim Pelancongan Bayaran Mudah}

Secara umumnya, Skim Bayaran Mudah (Easy-Payment Scheme) melibatkan bayaran kos pelancongan secara ansuran. Skim ini mewajibkan pembayaran deposit sebanyak RM500 seorang manakala baki bayaran boleh dibuat secara ansuran bulanan mengikut kemampuan ahli dan hendaklah dijelaskan sepenuhnya dalam tempoh 50 hari sebelum tarikh perjalanan. ${ }^{7}$

Namun realitinya, responden dalam kalangan ahli skim ini menyatakan bahawa skim pelancongan bayaran mudah hakikatnya ialah 'skim membuat hutang dengan mudah'. Kebanyakan agensi pelancongan yang menawarkan skim bayaran mudah menawarkan kaedah pembayaran yang tidak tetap dan akan berubah-ubah mengikut kehendak dan selera pengguna. Pembayaran akan ditentukan sama ada secara mingguan, bulanan atau tiga bulan sekali (Ibid).

Malahan, sekiranya perkiraan dan perbandingan secara mendalam dibuat antara harga tunai dan harga mengikut skim bayaran mudah, kadar harga yang ditawarkan adalah jauh berbeza di mana berlaku kenaikan harga hampir dua kali ganda atau lebih apabila pengguna menceburi skim pelancongan bayaran mudah. Situasi ini pada awalnya jarang diambil perhatian oleh mereka yang berkecimpung dalam hal ini sementelah pihak agensi acap kali mengaburi pengguna dengan tawaran yang kedengarannya berpihak kepada mereka seperti jaminan penginapan mewah dan sebagainya. Namun hakikatnya, terdapat yuran terselindung yang perlu dibiayai oleh pengguna (Ibid).

\footnotetext{
7 Aida Farihan M. Saleh@ Mohd Nawi (Pegawai Undang-Undang, Bahagian Undang-Undang KPDNKK), dalam temu bual beliau melalui panggilan telefon dengan penulis, 14 Mei 2015.
} 


\section{Skim Pelancongan Perkongsian Masa}

Skim Pelancongan Kongsi Masa (Time Share Vacation Scheme) merujuk kepada pembelian hak untuk menggunakan kemudahan percutian bagi satu masa tertentu dalam setahun untuk suatu tempoh tertentu. Skim ini adalah berdasarkan kepada konsep berkongsi kos percutian. Sebagai contoh, apabila seseorang membeli tiket penerbangan ke suatu destinasi, maka beliau akan berkongsi kos penerbangan tersebut dengan ahli-ahli lain yang berada di bawah skim ini. Pembeli keahlian dalam skim percutian kongsi masa juga akan berkongsi kos penginapan. Jenis penginapan mungkin berbeza-beza mengikut produk percutian kongsi masa yang dibeli, termasuk penggunaan hotel, pangsapuri, chalet dan sebagainya (Ibid).

Dalam hal ini, pengguna dinasihatkan supaya membaca prospektus ${ }^{8}$ dengan teliti untuk memastikan mereka peka dengan jenis penginapan yang disediakan. ${ }^{9}$ Hal ini kerana, taktik pemasaran yang digunakan oleh syarikat yang memasarkan keahlian skim perkongsian masa ini kadangkala mengelirukan pengguna. Pelanggan yang berpotensi akan dihampiri di pusat membeli belah, dihubungi melalui pos atau telefon, atau jemputan menghadiri seminar.

Bagi menarik kehadiran pelanggan, mereka dijanjikan dengan pelbagai tawaran menarik seperti pakej percutian secara percuma bersama pasangan masing-masing. Pelanggan juga dijanjikan bahawa tiada sebarang bayaran bakal dikenakan. Namun selepas taklimat diberikan, pelanggan seolah-olah dipaksa untuk membeli keahlian (Ibid).

Selain itu, kaedah pemasaran skim perkongsian masa dikawalselia oleh Akta Jualan Langsung dan Skim Anti Piramid 1993 (Akta 500). Peruntukan penting dalam Akta ini ialah mana-mana jualan yang melebihi RM300 hendaklah dibuat dalam bentuk kontrak bertulis kerana mengambil tempoh bertenang iaitu selama 10 hari bekerja. Hal ini memberi peluang kepada pengguna untuk berfikir sebaiknya dan secara rasional sebelum benar-benar bersetuju untuk menyertai skim tersebut. Namun, kebanyakan ahli skim tidak dimaklumkan

8 Dokumen sah yang mengandungi ciri-ciri penting skim percutian kongsi masa, termasuk hak pembeli dan kewajipan Syarikat Pengusaha/Pemaju percutian kongsi masa.

9 Pusat Khidmat Aduan Pengguna Nasional, "Info Pengguna-Time Share/Kongsi Masa”, Laman Sesawang Sinar Pusat Khidmat Aduan Pengguna Nasional Online, http://www.nccc.org.my/v2/index.php/time-share, dicapai 12 April 2015. 
tentang peraturan ini sehingga menyebabkan mereka membuat bayaran secara serta-merta. Ini bercanggah dengan fasa S25(4) iaitu: ${ }^{10}$

"Tiada penjual atau orang lain boleh menerima apa-apa wang atau balasan lain daripada pembeli di bawah sesuatu kontrak yang dibuat di bawah akta ini sebelum habis tempoh bertenang..."

Peruntukan dalam Akta Jualan Langsung dan Skim Anti Piramid 1993 sering tidak diendahkan oleh industri perkongsian masa. Rentetan itu, pihak berkuasa perlu menjalankan penyiasatan dengan menghadiri sesi penerangan oleh pengendali perkongsian masa, atau mendapatkan maklum balas daripada pengguna yang pernah menghadiri sesi penerangan perkongsian masa. ${ }^{11}$

Undang-undang baru yang mengawal selia semua aspek industri perkongsian masa perlu digubal bagi memberikan kuasa penuh kepada pihak berkuasa menyemak peruntukan kemudahan di bawah keahlian perkongsian masa. Pihak berkuasa juga diberi kuasa untuk memeriksa kemudahan dalam unit penginapan yang sediakan untuk ahli dan pelbagai kemudahan lain yang disediakan untuk mereka (Ibid).

Pada masa ini, tidak ada sebarang bentuk kawalan berkaitan kepentingan pengguna dalam industri perkongsian masa. Peraturan yang ada ialah Akta Jualan Langsung dan Skim Anti Piramid 1993 yang tidak mempunyai peruntukan yang jelas untuk menyelesaikan masalah berkaitan industri ini. Akta ini hanya mengawal selia proses jualan langsung kepada pengguna.

Terdapat banyak aspek dalam industri perkongsian masa yang perlu dikawal selia oleh Kementerian Perdagangan Dalam Negeri dan Hal Ehwal Pengguna ( $\mathrm{Ibid}$ ). Justeru itu, penyelidikan ini dilaksanakan bagi mengkaji dan menganalisis penyelesaian-penyelesaian yang komprehensif bagi mengatasi permasalahan yang dihadapi oleh ahli-ahli Skim Pelancongan Perkongsian Masa merangkap kepada pengguna skim ini.

\section{UNDANG-UNDANG BERKAITAN PERLINDUNGAN SKIM PELANCONGAN DAN PENGUATKUASAANNYA}

Pada dasarnya, adalah mustahil untuk mewujudkan satu undang-undang yang memberi peruntukan khusus berkenaan skim pelancongan kerana skim ini dirangka dengan merujuk kepada pelbagai akta. Skim Pelancongan Kongsi

\footnotetext{
${ }^{10}$ Seksyen 25(4) Akta Jualan Langsung dan Skim Anti Piramid 1993 (Akta 500).

${ }^{11}$ Pusat Khidmat Aduan Pengguna Nasional, "Info Pengguna- Time Share/Kongsi Masa", Sinar Pusat Khidmat Aduan Pengguna Nasional Online, http://www.nccc. org.my/v2/index.php/time-share, dicapai 12 April 2015.
} 
Masa adalah contoh skim yang terikat dengan Akta Jualan Langsung dan Skim Anti Piramid 1993 manakala skim-skim yang mengandungi iklan pula terikat dengan garis panduan dan peraturan periklanan yang dikeluarkan oleh Kementerian Perdagangan Dalam Negeri, Koperasi dan Kepenggunaan.

Namun, dalam hal melibatkan perlindungan pengguna ke atas Skim Pelancongan di Malaysia terdapat tiga akta utama yang digunapakai iaitu Akta Perlindungan Pengguna 1999, Akta Kontrak 1950, dan Akta Industri Pelancongan 1992 (Nuraisyah Chua Abdullah, 2013: 9).

Akta utama yang digunapakai bagi mengawal dan melindungi para pengguna ialah:

\section{Akta Industri Pelancongan 1992 (Akta 482) dan Peraturan-Peraturan}

Akta Industri Pelancongan 1992 (Akta 482) merupakan akta yang memperuntukkan pelesenan dan pengawalseliaan pengusahaan pelancongan serta perkara-perkara yang bersampingan atau berkaitan dengannya. Akta ini mengandungi lima bahagian utama merangkumi Bahagian I; Permulaan, Bahagian II; Pelesenan Pengusahaan-pengusahaan Pelancongan, Bahagian III; Kehendak dan Kewajipan ke atas Pengusahaan-pengusahaan Pelancongan Berlesen, Bahagian IV; Pelesenan Pemandu-pemandu Pelancong,Bahagian IVA; Pendaftaran Premis Penginapan, dan Bahagian V; Am. Akta ini turut disertakan dengan Peraturan-peraturan bagi industri pelancongan.

Perkara utama bagi memastikan suatu undang-undang itu melindungi pengguna ialah dengan melihat kepada keesahan skim pelancongan tersebut. Terdapat beberapa peruntukan dalam Akta Industri Pelancongan 1992 (Akta 482) yang membolehkan sesuatu skim pelancongan yang dikeluarkan agensi menjadi sah.

Seksyen 5(1)(2) dalam Bahagian II Akta 482 memperuntukkan berkenaan Pelesenan Pelesenan Pengusahaan Pelancongan yang menghendaki sesuatu pengusahaan pelancongan agar dilesenkan. Kegagalan mengemukakan lesen menyebabkan agensi yang dikendalikan adalah tidak sah dan berjalan tanpa adanya kebenaran daripada pihak berkuasa (Ibid). Seksyen 5(1) dan (2) menyatakan:

1) "Tiada seorang pun boleh menjalankan atau mengendalikan, atau mengemukakan dirinya sebagai menjalankan atau mengendalikan institusi latihan pelancongan melainkan jika orang itu memegang suatu lesen yang sah yang diberikan di bawah Bahagian ini. 


\section{2) "Tiada seorang pun boleh menjalankan atau mengendalikan, atau menganjurkan dirinya sebagai menjalankan atau mengendalikan:}

(a) Perniagaan pengendalian pelancongan; atau

(b) Perniagaan agensi pengembaraan.

melainkan jika ia adalah suatu syarikat dan memegang lesen sah yang diberikan di bawah Bahagian ini."

Seksyen 19 Akta 482 pula menyentuh perihal Pengambilan Kerja Pemandu Pelancong Berlesen. Khidmat pemandu pelancong adalah penting bagi pengguna yang pertama kali bercuti ke suatu tempat dan semestinya memerlukan pemandu arah.

Lantaran itu, skim pelancongan pada kebiasaannya sering menjadikan pakej pemandu pelancong sebagai salah satu tarikan tambahan (Ibid). Undangundang mensyaratkan setiap pemandu pelancong yang dilantik oleh agensi perlu memiliki lesen yang sah. Kegagalan berbuat demikian boleh dihukum jika sabit kesalahan dengan denda tidak melebihi dua puluh ribu ringgit atau dipenjarakan selama tempoh tidak melebihi dua tahun atau kedua-duanya sebagaimana yang diperuntukkan dalam Seksyen 19 (1) dan (2).

Selain itu, dalam menjalankan tugas-tugas penguatkuasaan, Akta 482 ini memberi kuasa kepada mana-mana pegawai untuk menjalankan proses penyiasatan dan pendakwaan sebagaimana yang diperuntukkan oleh 3942 yang secara ringkas menyebut berkenaan kuasa untuk mengkompaun kesalahan, pegawai diberi kuasa, kuasa untuk menyiasat dan kuasa untuk memeriksa saksi (Ibid).

Bagi menjalankan kuasa pendakwaan, Seksyen 49 memperuntukkan berkenaan penjalanan pendakwaan dengan memperuntukkan bahawa setiap pegawai yang telah diberi kuasa berhak untuk hadir ke mahkamah dan menjalankan apa-apa kes pendakwaan melibatkan kesalahan terhadap Akta ini (Ibid).

Dalam Bahagian V Akta 482 pula memperuntukkan berkenaan penalti am bagi kesalahan-kesalahan yang tiada penalti khusus mengikut peruntukan seksyen mereka. Sebagai contoh, Seksyen 37 memperuntukkan bahawa orang yang melakukan kesalahan di bawah Akta ini yang tiada penalti khusus disediakan bagi kesalahan tersebut apabila disabitkan boleh didenda tidak melebihi lima ribu ringgit atau dipenjarakan selama tempoh tidak melebihi tiga tahun atau kedua-duanya, dan dalam hal suatu kesalahan yang berterusan, 
boleh, sebagai tambahan, didenda tidak melebihi lima ratus ringgit bagi setiap hari kesalahan itu terus dilakukan.

\section{Akta Perlindungan Pengguna 1999 (Akta 599)}

Akta Pelindungan Pengguna 1999 merupakan akta yang memperuntukkan perkara berkenaan pelindungan ke atas pengguna, penubuhan Majlis Penasihat Pengguna Negara dan Tribunal Tuntutan Pengguna, dan bagi perkara perkara yang berkaitan dengannya. Objektif penggubalan akta ini adalah untuk menentukan tidak wujud perlakuan mengelirukan dan memperdaya, representasi palsu serta amalan tidak saksama yang dilakukan oleh peniaga serta memastikan pengguna terjamin ke atas keselamatan barang dan perkhidmatan yang diperolehi.

Akta 599 mengandungi 14 bahagian merangkumi 150 seksyen yang mengandungi isu perundangan yang tidak dinyatakan oleh akta-akta lain. Akta ini juga memperkenalkan satu badan yang dinamakan Tribunal Tuntutan Pengguna. Tribunal berhak mendengar tuntutan yang berjumlah tidak lebih daripada RM10 ribu dan pihak-pihak yang terlibat tidak boleh diwakili oleh peguamcara dan peguambela.

Dalam maksud memberi perlindungan ke atas pengguna, skim pelancongan yang dikeluarkan oleh agensi-agensi pelancongan haruslah jelas dan tidak mengandungi tawaran, terma, mahupun iklan yang mengelirukan. Seksyen 9 Akta 599 memperuntukkan berkenaan perlakuan yang mengelirukan dengan menyebut bahawa (Ibid):

"Tiada seorang pun boleh melibatkan diri dalam perlakuan yang:

Berhubung dengan perkhidmatan, adalah mengelirukan atau memperdayakan, atau mungkin mengelirukan atau memperdayakan, orang ramai mengenai sifat, ciri-ciri, kesesuaian bagi sesuatu maksud, atau kuantiti, perkhidmatan itu..."

Selain itu, Seksyen 14 Akta 599 pula memperuntukkan berkenaan pemberian, hadiah, tawaran percuma, dan pelbagai tawaran lain termasuklah apa-apa jenis perkhidmatan dengan mensyaratkan agar pemberian tidak dibuat atas tujuan untuk tidak mengadakannya sebagai tarikan semata-mata atau dengan tujuan untuk mengadakannya namun bukan seperti yang ditawarkan. Seksyen 14 (1) memperuntukkan bahawa (Ibid): 
(1) "Tiada seorang pun boleh menawarkan apa-apa pemberian, hadiah atau benda percuma lain:

(a) dengan niat untuk tidak mengadakannya; atau

(b) dengan niat untuk tidak mengadakannya sebagaimana yang ditawarkan..."

Seterusnya, bahagian IV Akta 599 ini memperuntukkan hukuman ke atas pelanggaran di dalam Bahagian II dan III serta pembelaan dan remedi yang boleh dituntut oleh pengguna. Seksyen 25 memperuntukkan bahawa (Ibid):

(1) "Mana-mana orang yang melanggar mana-mana peruntukan Bahagian II dan III melakukan suatu kesalahan dan apabila disabitkan boleh:

(a) Jika orang itu suatu pertubuhan perbadanan, didenda tidak melebihi dua ratus lima puluh ribu ringgit dan bagi kesalahan kali kedua atau yang berikutnya, boleh didenda tidak melebihi lima ratus ribu ringgit;

(b) Jika orang itu bukan suatu pertubuhan perbadanan, didenda tidak melebihi satu ratus ribu ringgit atau dipenjarakan selama tempoh tidak melebihi tiga tahun atau kedua-duanya, dan bagi kesalahan kali kedua atau yang berikutnya, boleh didenda tidak melebihi dua ratus lima puluh ribu ringgit atau dipenjarakan selama tempoh tidak melebihi enam tahun atau kedua-duanya.

(2) Dalam hal kesalahan yang berterusan, pesalah hendaklah, sebagai tambahan kepada penalti di bawah subseksyen (1), boleh didenda tidak melebihi satu ribu ringgit bagi setiap hari atau sebahagian hari selama kesalahan itu berterusan selepas sabitan..."

Seksyen ini secara ringkasnya memberi hukuman ke atas pelanggaran yang telah disyaratkan dalam bahagian II dan III Akta Perlindungan Pengguna 1999 ini. Hukuman itu adalah berbentuk denda dan penjara sebagaimana yang dinyatakan dalam peruntukan di atas. Sebaliknya, dalam hal kesalahan yang berterusan, pesalah hendaklah, sebagai tambahan kepada penalti di bawah subseksyen (1), boleh didenda tidak melebihi satu ribu ringgit bagi setiap hari atau sebahagian hari selama kesalahan itu berterusan selepas sabitan.

Dalam aspek penguatkuasaan, Bahagian XIII Akta Perlindungan Pengguna 1999 memperuntukkan berkenaan pemeriksaan dengan waran, penggeledahan dan penyitaan tanpa waran, senarai barang disita, kuasa untuk menghendaki 
kehadiran orang yang mempunyai pengetahuan tentang kes, perlindungan pemberi maklumat dan sebagainya (Ibid). Perihal penguatkuasaan ada terkandung dalam Seksyen 123-139 yang antaranya memperuntukkan berkenaan kuasa penyiasatan dan kad kuasa dengan menyebut bahawa:

(123) "Seseorang Penolong Pengawal hendaklah mempunyai kuasa untuk menyiasat pelakuan apa-apa kesalahan di bawah Akta ini..." (Ibid)

(124) "Seseorang Penolong Pengawal semasa bertindak di bawah Akta ini hendaklah apabila diminta menyatakan jawatannya dan mengemukakan kepada orang yang terhadapnya dia bertindak itu atau yang daripadanya dia meminta apa-apa maklumat apaapa kad kuasa sebagaimana yang diarahkan oleh Pengawal supaya dibawa oleh pegawai itu..." (Ibid)

Peruntukan-peruntukan yang disebutkan merupakan contoh-contoh dan bentuk-bentuk penguatkuasaan yang boleh dilakukan oleh Pegawai Penguatkuasa di bawah Unit Penguatkuasaan KPDNKK. Mereka boleh bertindak dan mempunyai kuasa menyiasat apa-apa aduan yang dibuat oleh pengguna berkaitan dengan skim pelancongan berdasarkan kepada kuasa yang diberikan oleh seksyen ini.

\section{Akta Kontrak 1950 (Akta 136)}

Undang-undang kontrak di Malaysia ditadbir oleh Akta Kontrak 1950. Akta ini mengandungi peruntukan berkenaan pembentukan kontrak, pelaksanaannya dan peruntukan berkaitan dengan agensi. Walau bagaimanapun, akta ini masih belum merangkumi segala aspek undang-undang kontrak. Hal ini kerana, Akta Kontrak tidak mengandungi apa-apa peruntukan yang memperkatakan khususnya tentang isi kandungan sesuatu kontrak.

Tiada peruntukan yang dibuat tentang pengkelasan terma dan juga takat obligasi pihak-pihak kepada kontrak. Akta ini juga membisu tentang sama ada pihak-pihak adalah secara tegasnya terikat oleh terma nyata kontrak atau sama ada terma tertentu boleh disiratkan. Akta 1950 hanya cuba mengkodifikasikan prinsip-prinsip asas undang-undang kontrak dan hanya mengandungi peruntukan khusus yang mengawal kandungan atau terma kontrak.

Justeru, tiada peruntukan mengenai fasal yang membataskan biarpun mengecualikan liabiliti satu pihak, fasal yang memasukkan terma dalam dokumen lain ke dalam kontrak. Oleh sebab itu, rujukan kepada undangundang Inggeris adalah dibenarkan apabila wujud kekurangan di dalam Akta 
136 melalui peruntukan Seksyen 3 dan 5 Akta Undang-undang Sivil 1956 (Sakina Shaik Ahmad Yusoff, Azimon Abdul Aziz, 2012: 1).

Pada dasarnya, skim pelancongan juga melibatkan satu kontrak dan perjanjian. Hal ini kerana, wujudnya elemen tawaran, penerimaan dan balasan daripada pihak-pihak yang berkontrak sekaligus menyebabkan pakej yang ditawarkan di dalam skim tersebut boleh dilaksanakan (Nuraisyah Chua Abdullah, 2013: 13-14). Lantaran itu, pihak-pihak yang terlibat juga adalah terikat dengan undang-undang kontrak. Akta 136 mendefinisikan kontrak sebagai satu perjanjian yang boleh dikuatkuasakan oleh undang-undang. Definisi ini terkandung dalam Seksyen 2(h) yang memperuntukkan bahawa:

"Kontrak adalah perjanjian yang boleh dikuatkuasakan oleh undang-undang. Ia adalah perjanjian yang akan mengikat pihakpihak yang berkontrak. Jika ada pihak yang tidak menepati perjanjian ini, maka pihak lain boleh dan berhak mengambil tindakan undang-undang..."

Selain itu, Seksyen 38(1) dalam akta yang sama turut memperuntukkan berkenaan kewajipan melaksanakan kontrak dengan menyebut bahawa:

"Pihak-pihak suatu kontrak wajib melaksanakan atau wajib menawar untuk melaksanakan janji mereka masing-masing, melainkan jika pelaksanaan sedemikian itu telah dilepaskan atau dimaafkan oleh peruntukan-peruntukan ordinan ini atau manamana undang-undang lain..."

Dalam keadaan jika salah satu pihak kepada kontrak yang dipersetujui dalam sesuatu skim pelancongan ini meninggal dunia sebelum sempat melaksanakan kewajipannya menurut kontrak itu, maka pelaksanaan kontrak tersebut akan diteruskan oleh wakil-wakil si mati. Perkara ini dijelaskan oleh Seksyen 38(2) Akta Kontrak 1950 (Ibid):

"Janji-janji adalah mengikat wakil-wakil pembuat janji, pembuat janji apabila matinya pembuat janji sebelum pelaksanaanya, melainkan jika ternyata niat yang berlawanan dalam kontrak itu..."

Seterusnya, Bahagian VII Akta Kontrak 1950 menyatakan perihal Akibat Pelanggaran Kontrak di mana bahagian ini memperuntukkan pampasan bagi kerugian atau kerosakan yang disebabkan oleh pelanggaran kontrak. Pembatalan satu kontrak dalam skim pelancongan yang dibuat secara sah adalah berhak mendapat pampasan bagi sebarang kerugian yang dialaminya kerana ketiadaan pemenuhan kontrak itu. Hal ini disebutkan dalam Seksyen 76 yang menyebut bahawa (Ibid): 
"Seseorang yang mendapat pembatalan kontrak berhakmendapat pampasan bagi apa-apa kerosakan yang telah ditanggung melalui tidak memenuhi kontrak..."

Akta Kontrak 1950 sebenarnya merupakan satu akta yang mengkodifikasikan prinsip-prinsip asas undang-undang kontrak. Oleh sebab itu, dalam maksud menjalankan tugas penguatkuasaan, akta ini tidak mempunyai peruntukan khusus yang mengawal kandungan atau terma kontrak.

Justeru, bagi penguatkuasaan ke atas pelanggaran undang-undang kontrak, tiada peruntukan khusus yang boleh dijadikan garis panduan namun pihakpihak yang telah dicabuli haknya melalui pelanggaran kontrak boleh terus membuat aduan di Bahagian Tribunal Tuntutan Pengguna (Sakina Shaik Ahmad Yusoff, et al., t.t.: 39).

Oleh hal yang demikian, skim pelancongan di Malaysia pada asasnya merupakan satu pelan atau rancangan percutian pelbagai bentuk. Terdapat tiga undang-undang utama yang memperuntukkan skim pelancongan di Malaysia merangkumi Akta Industri Pelancongan 1992 (Akta 482) dan PeraturanPeraturan, Akta Perlindungan Pengguna 1999 (Akta 599) dan Akta Kontrak 1950 (Akta 136). Akta-akta ini menyatakan tentang undang-undang yang perlu dipatuhi oleh setiap agensi pelancongan yang menawarkan perkhidmatan pemandu pelancong, petempatan, dan lain-lain.

\section{REMEDI DI BAWAH TRIBUNAL TUNTUTAN PENGGUNA MALAYSIA}

Dalam sektor pelancongan, isu berbangkit yang sering menjadi polemik adalah berkaitan penipuan ke atas pengguna oleh agensi-agensi pelancongan. Buletin kepenggunaan dalam laporannya menyatakan bahawa sindiket penipuan pakej umrah dan pakej harga runtuh oleh agensi pelancongan menarik perhatian masyarakat semula sejak awal bulan Ogos tahun 2014. Terbaru, Biro Aduan Awam MCA melaporkan sindiket agensi pelancongan tidak berlesen dipercayai mengaut keuntungan lebih RM10 juta selepas memperdaya 20,000 mangsa di seluruh negara.

Menurut laporan Pusat Khidmat Aduan Pengguna Nasional (NCCC) pula, aduan pengguna berkaitan agensi pelancongan dilaporkan meningkat sebanyak 28.6\% pada tahun 2014 dengan nilai kerugian RM1.4 juta berbanding tahun 2013 dengan nilai kerugian RM1.2 juta. Berdasarkan rekod NCCC, penipuan pakej pelancongan berlaku melibatkan agensi yang berdaftar mahupun tidak berdaftar secara sah. Antara aduan yang popular, pengguna diminta membayar deposit sebanyak $50 \%$ dan pada saat akhir pengguna dimaklumkan bahawa lokasi atau penginapan yang dijanjikan tidak dapat disediakan. Pakej tidak 
memuaskan, pakej dikatakan mahal. Paling mengejutkan agensi tidak dapat dihubungi pada tarikh yang ditetapkan. ${ }^{12}$

Dalam usaha menyelesaikan isu ini, pada dasarnya segala pertelingkahan, ketidakpuasan hati dan penindasan yang dialami oleh pengguna khususnya dalam aspek skim pelancongan ini hendaklah diadukan terus kepada pihak mahkamah. Namun begitu, adalah lumrah bagi sesuatu proses mahkamah itu untuk mengambil masa yang panjang kerana perjalanan mahkamah melibatkan prosedur perundangan yang pelbagai (Ibid).

Tambahan pula, yuran dan bayaran yang agak tinggi mungkin dikenakan ke atas pengadu lebih-lebih lagi sekiranya pihak-pihak diwakili oleh peguam. Maka, dengan sebab itu ramai pengguna lebih rela berdiam diri dan tidak mengambil tindakan ke mahkamah (Ibid).

Memahami hakikat ini Tribunal Tuntutan Pengguna Malaysia (TTPM) telah ditubuhkan bagi menyediakan satu saluran atau kemudahan alternatif kepada seorang pengguna untuk menuntut gantirugi dan pampasan daripada manamana agensi atau syarikat pelancongan dengan cara mudah, murah dan cepat. TTPM bukanlah satu pusat pengadilan di bawah badan kehakiman negara, namun ia tetap berfungsi seperti mahkamah. Para pengguna yang terpedaya dengan skim pelancongan yang tidak jujur boleh menuntut remedi di bahagian tribunal ini. ${ }^{13}$

Timbalan Pengerusi, Tribunal Tuntutan Pengguna Malaysia, Mohammad Nordin Ab. Rauf menyatakan bahawa pihak tribunal hanya berbidangkuasa untuk membuat rujukan ke atas perkara-perkara di dalam Akta Perlindungan Pengguna 1999 sahaja. Manakala, rujukan ke atas akta-akta lain boleh dibuat kepada Mahkamah Sivil (Mahkamah Majistret) kerana hanya mahkamah yang berbidangkuasa mengenainya (Ibid).

Tambah beliau lagi, walaupun pihak tribunal hanya tertumpu kepada undang-undang perlindungan pengguna, namun presiden dan keanggotaannya yang lain adalah mereka yang amat mahir dengan undang-undang di Malaysia. Mohammad Nordin Ab. Rauf sendiri mempunyai pengalaman selama 15

${ }^{12}$ Pusat Khidmat Aduan Pengguna Nasional, "Info Pengguna- Time Share/Kongsi Masa", Sinar Pusat Khidmat Aduan Pengguna Nasional Online, http://www.nccc. org.my/v2/index.php/time-share, dicapai 28 Mei 2015.

${ }^{13}$ Kementerian Perdagangan Dalam Negeri, Koperasi dan Kepenggunaan, “Tribunal Tuntutan Pengguna Malaysia”, Kementerian Perdagangan Dalam Negeri, Koperasi dan Kepenggunaan Online, https://ttpm.kpdnkk.gov.my/portal/index.php/my/, dicapai 26 Mei 2015. 
tahun beramal sebagai hakim di mahkamah dan 2 tahun sebagai Presiden di Tribunal. ${ }^{14}$

Beliau mengulas bahawa, undang-undang yang menyentuh berkenaan skim pelancongan sama ada dari aspek kontrak, pemandu pelancong, fee, tempat percutian, dan perkhidmatan-perkhidmatan lain adalah amat mencukupi dan memadai sebagaimana berikut (Ibid):

"Sememangnya undang-undang yang sudah ada ini cukup. Sebab undang-undang ini kita buat bukan hanya untuk diikuti tetapi disukai, dengan harapan kita mampu melaksanakannya dengan mudah dan sistematik. Lebih-lebih lagi dalam industri pelancongan, pun dah ada akta sendiri (Akta Industri Pelancongan 1992 dan Peraturan-peraturan). Kalau lah undangundang yang dah ada ni tak cukup, sudah tentu kita ada masalah dalam pelaksanaan. Tapi setakat ni semua baik..."

Menurut beliau lagi, pihak tribunal akan membela mana-mana pengguna yang tertindas dengan melihat kepada kualiti barangan atau perkhidmatan yang diberikan oleh pihak agensi. Hal ini kerana, Akta Perlindungan Pengguna 1999 secara umum memberi hak kepada pengguna untuk mendapatkan gantirugi kepada barangan atau perkhidmatan; termasuklah pelancongan yang tidak berkualiti sebagaimana yang dijanjikan dalam skim atau pakej percutian mereka (Ibid).

Maka, seseorang pelanggan yang tidak berpuas hati dengan tempat penginapan yang disediakan, ${ }^{15}$ pihak tribunal tidak akan merujuk kepada Akta Industri Pelancongan 1992 namun terus merujuk kepada Akta Perlindungan Pengguna 1999. ${ }^{16}$ Sekiranya perkara yang diadukan itu berbentuk khusus seperti tarik balik kontrak, atau melibatkan perihal iklan yang mengelirukan di dalam skim pelancongan, maka hal tersebut boleh diadukan ke mahkamah. Oleh itu, tiada alasan mahupun ruang untuk menyatakan undang-undang sedia ada masih belum mencukupi. Undang-undang ini sudah cukup, malah berupaya untuk melindungi pengguna kerana itu tujuan utama ia digubal. ${ }^{17}$

Selain itu, dari sudut pelaksanaan undang-undang sedia ada yang melibatkan skim pelancongan, Mohammad Nordin Ab. Rauf selaku

\footnotetext{
${ }^{14}$ Mohammad Nordin Ab. Rauf (Timbalan Pengerusi, Tribunal Tuntutan Pengguna Malaysia, TTPM), dalam temu bual beliau dengan penulis, 26 Mei 2015.

${ }^{15}$ Seksyen 31A, Akta Industri Pelancongan 1992 dan Peraturan-Peraturan (Akta 482).

${ }^{16}$ Akta Perlindungan Pengguna 1999 (Akta 599).

${ }^{17}$ Mohammad Nordin Ab. Rauf (Timbalan Pengerusi, Tribunal Tuntutan Pengguna Malaysia, TTPM), dalam temu bual beliau dengan penulis, 26 Mei 2015.
} 
pengamal undang-undang yang berpengalaman menyatakan bahawa setakat ini tiada permasalahan besar dalam melaksanakan undang-undang berkaitan pelancongan. Beliau mengulas sebagaimana berikut (Ibid):

"Pelaksanaan undang-undang baik. Setakat ini tiada masalah besar yang berlaku. Halangan-halangan yang ada cuma dari sudut teknikal macam kekurangan penguatkuasa, tapi itu semua sudah kita atasi dari masa ke masa..."

Beliau turut menambah bahawa secara realiti, undang-undang yang diperuntukkan di dalam akta itu adalah dilaksanakan sebagaimana yang diteorikan. Namun, dalam beberapa situasi, pihak tribunal mengambil langkah untuk memudahkan proses perbicaraan pihak-pihak. Sebagai contoh, sekiranya keterangan dan bukti telah mencukupi, maka pihak-pihak akan terus dipanggil tanpa menunggu tempoh 14 hari sebagaimana yang ditetapkan oleh prosedur dalam pengadilan (Ibid).

\section{ANALISIS STATISTIK BILANGAN PEMFAILAN DAN NILAI TUNTUTAN BAGI KES BERKAITAN AGENSI PELANCONGAN TAHUN 2014 DAN 2015}

Berdasarkan kupasan dan perbincangan sebelum ini, satu kesimpulan awal boleh dibuat dengan pernyataan bahawa undang-undang sedia ada memang sudah mencukupi. Pelaksanaan ke atas undang-undang berkaitan skim pelancongan juga adalah baik dan sistematik. Namun, malangnya masih banyak lagi kes-kes melibatkan pengguna yang tertipu dan terpedaya dengan agensi-agensi pelancongan melaui skim yang mereka sediakan ini. ${ }^{18}$

Menurut Mohammad Nordin Ab. Rauf, masih terdapat banyak kes melibatkan agensi-agensi pelancongan yang cuba memperdaya para pengguna yang tertarik dengan skim yang ditawarkan mereka. Contohnya, satu kes penipuan pakej umrah dan ziarah yang menawarkan kos tambang murah di bawah RM5,000 disertakan dengan petempatan hotel mewah (Hotel Hilton) dan pakej pelancongan ke Turki dengan anggaran kos sebenar adalah RM11,000. ${ }^{19}$

Statistik Kementerian Pelancongan dan Kebudayaan dari 2012 hingga 2016 menunjukkan 54 kes penipuan pakej umrah direkodkan dengan jumlah denda dan kompaun melebihi RM 237,000. Jumlah ini termasuk syarikat dan agensi

\footnotetext{
${ }^{18}$ Kesimpulan ringkas dibuat berdasarkan temu bual bersama Mohammad Nordin Ab. Rauf.

${ }^{19}$ Mohammad Nordin Ab. Rauf (Timbalan Pengerusi, Tribunal Tuntutan Pengguna Malaysia, TTPM), dalam temu bual beliau dengan penulis, 26 Mei 2015.
} 
pelancongan umrah dan pengembaraan ke luar negara (outbound) yang telah dikenakan tindakan pembatalan lesen oleh pihak berkuasa seperti Seven Seas Travel \& Tours, Irna Yakin Travel \& Tours Sdn. Bhd. dan J\&J Travel \& Tours. ${ }^{20}$ Jadual 1: Bilangan Pemfailan Bagi Kes Berkaitan Agensi Pelancongan Tahun 2014 dan $2015^{21}$

\begin{tabular}{lcc}
\hline & $\mathbf{2 0 1 4}$ & $\mathbf{2 0 1 5}$ \\
\cline { 2 - 3 } & Bilangan Pemfailan & Bilangan Pemfailan \\
\hline Perlis & 0 & 0 \\
Kedah & 21 & 16 \\
Pulau Pinang & 21 & 0 \\
Perak & 32 & 4 \\
Selangor & 57 & 2 \\
WP Kuala Lumpur & 103 & 20 \\
WP Putrajaya & 44 & 3 \\
Negeri Sembilan & 15 & 3 \\
Melaka & 8 & 5 \\
Johor & 26 & 4 \\
Pahang & 4 & 2 \\
Terengganu & 20 & 1 \\
Kelantan & 1 & 8 \\
Sabah & 6 & 1 \\
WP Labuan & 0 & 0 \\
Sarawak & 9 & 8 \\
\hline Jumlah & 367 & 77 \\
\hline
\end{tabular}

Sumber: Unit Pendaftaran Tribunal Tuntutan Pengguna Malaysia Bagi Tahun 2014-2015.

Merujuk kepada statistik mengenai Bilangan Pemfailan dan Nilai Tuntutan Bagi Kes Berkaitan Agensi Pelancongan yang dikeluarkan oleh Unit Pendaftaran Tribunal Tuntutan Pengguna Malaysia, telah menunjukkan berlakunya peningkatan dari tahun 2013 hingga tahun 2015. Manakala,

${ }^{20}$ Berita Harian, "12 Syarikat Dibatal Lesen Kerana Kes Penipuan Umrah", Laman Sesawang Berita Harian Online, http://www.bharian.com.my/node/131665, dicapai 7 Mac 2016.

${ }^{21}$ Bilangan Pemfailan Bagi Kes Berkaitan Agensi Pelancongan yang dikeluarkan oleh Unit Pendaftaran Tribunal Tuntutan Pengguna Malaysia Bagi Tahun 2014-2015. 
statistik terkini bagi Januari 2014 hingga April 2015 pula menunjukkan Wilayah Persekutuan Kuala Lumpur telah mencatatkan bilangan pemfailan tertinggi berbanding negeri-negeri lain di Malaysia. Sebanyak 123 fail kes telah didaftarkan ${ }^{22}$ diikuti dengan Selangor sebanyak 59 fail kes dan Wilayah Persekutuan Putrajaya sebanyak 47 fail kes (Ibid).

Seterusnya, jumlah fail kes yang didaftarkan dari Januari 2014 sehingga April 2015 bagi negeri Kedah, Perak, dan Johor, masing-masing adalah sebanyak 37, 36, dan 30 fail kes yang berdaftar. Manakala, Pulau Pinang dan Terengganu masing-masing mencatatkan jumlah fail kes yang sama iaitu sebanyak 21 fail yang didaftarkan. Negeri Sembilan, Melaka, dan Pahang pula masing-masing mencatatkan 18, 13, dan 6 fail kes berdaftar. Sarawak, Kelantan dan Sabah mencatatkan kedudukan 3 terendah bagi bilangan fail kes yang didaftarkan iaitu masing-masing sebanyak 17, 9 dan 7 fail kes yang didaftakan. Bagi negeri Perlis dan Wilayah Persekutuan Labuan belum direkodkan adanya fail kes yang didaftarkan (Ibid).

Melihat kepada pola bagi bilangan fail kes yang melibatkan penipuan dalam skim percutian ini, setiap negeri menunjukkan pola yang berbeza dengan peratusan yang tidak sekata. Namun, jelas dapat dilihat bahawa ketiga-tiga negeri yang mencatatkan jumlah fail kes tertinggi iaitu Wilayah Persekutuan Kuala Lumpur, Selangor dan Wilayah Persekutuan Putrajaya merupakan negeri-negeri yang lebih pesat membangun yang menjalankan kerja-kerja pentadbiran dan perindustrian bagi Malaysia. Kapasiti penduduknya adalah besar dan lebih bersifat agresif apabila berhadapan dengan kes penipuan. Ini merupakan faktor utama ketiga-tiga negeri ini mencatatkan jumlah tertinggi bagi bilangan fail kes yang didaftarkan. ${ }^{23}$

Sebaliknya, antara faktor bagi Wilayah Persekutuan Labuan dan Perlis yang mencatatkan sifar bilangan kes adalah kawasannya yang agak kecil dengan kapasiti penduduk yang sedikit menjadi punca tidak terdapat fail kes yang didaftarkan bagi negeri-negeri ini.

Mohammad Nordin Ab. Rauf menegaskan bahawa peningkatan bilangan pemfailan kes ini bukanlah menunjukkan penguatkuasaan dan pelaksanaan

${ }^{22}$ Berdasarkan statistik Bilangan Pemfailan dan Nilai Tuntutan Bagi Kes Berkaitan Agensi Pelancongan Tahun 2014 dan 2015 yang dikeluarkan oleh Unit Pendaftaran Tribunal Tuntutan Pengguna Malaysia Bagi Tahun 2014-2015 (Lihat Jadual 1.0 di halaman 70).

${ }^{23}$ Berdasarkan statistik Bilangan Pemfailan dan Nilai Tuntutan Bagi Kes Berkaitan Agensi Pelancongan Tahun 2014 dan 2015 yang dikeluarkan oleh Unit Pendaftaran Tribunal Tuntutan Pengguna Malaysia Bagi Tahun 2014-2015 (Lihat Jadual 1.0 di halaman 70). 
undang-undang yang lemah, sebaliknya ia menjadi tanda aras bahawa kesedaran pengguna untuk tampil ke hadapan bagi menuntut hak-hak mereka semakin meningkat. ${ }^{24}$

Tambah beliau lagi, pada awal tahun 2000 bilangan kes yang didaftarkan adalah sangat sedikit dan hampir tiada di kebanyakan negeri khususnya Perlis, Pahang, Kelantan, Melaka dan Wilayah Persekutuan Labuan. ${ }^{25}$

Analisis pelaksanaan dan penguatkuasaan undang-undang menunjukkan peruntukan sedia ada mampu melindungi pengguna melalui badan terlatih serta prosedur yang tersusun dan sistematik sejajar dengan pelbagai program yang telah dilaksanakan oleh pihak Kerajaan seperti kempen kesedaran pengguna yang diadakan setiap tahun dan ceramah kepenggunaan yang diadakan secara berkala di setiap negeri. ${ }^{26}$

Namun, sikap segolongan pihak sama ada agensi-agensi pelancongan mahupun pengguna itu sendiri yang perlu memilih untuk bersikap jujur dalam menjalankan amanah atau bersikap tamak dan cuai. Mohammad Nordin Ab. Rauf menyatakan bahawa:

"No matter how good the law is, it will not protect you against your own greed and negligence..." 27

Peningkatan bilangan fail kes yang didaftarkan dari tahun ke tahun juga menunjukkan undang-undang yang telah diperuntukkan berjaya dikuatkuasakan dan dilaksanakan dengan sistematik. Melalui mekanisme perundangan ini, para pengguna yang teraniaya dengan agensi-agensi pelancongan melalui skim pelancongan yang ditawarkan oleh mereka mampu menuntut semula hak dan remedi dalam bentuk bayaran balik sama ada secara keseluruhan atau sebahagiannya.

Statistik peningkatan bilangan pemfailan kes ini juga bukanlah menjadi kayu ukur kegagalan undang-undang, sebaliknya ia berpunca daripada sikap segelintir pihak yang tamak dan ingin mengaut keuntungan semata-mata (Ibid). Dalam satu kes yang dilaporkan, terdapat satu sindiket daripada agensi pelancongan tidak berdaftar yang menyamar sebagai kakitangan Lembaga

\footnotetext{
${ }^{24}$ Mohammad Nordin Ab. Rauf (Timbalan Pengerusi, Tribunal Tuntutan Pengguna Malaysia, TTPM), dalam temu bual beliau dengan penulis, 26 Mei 2015.

${ }^{25}$ Mohammad Nordin Ab. Rauf (Timbalan Pengerusi, Tribunal Tuntutan Pengguna Malaysia, TTPM), dalam temu bual beliau dengan penulis, 26 Mei 2015.

${ }^{26}$ Buletin Kepenggunaan yang dikeluarkan oleh KPDNKK, vol. 3 tahun 2015.

${ }^{27}$ Mohammad Nordin Ab. Rauf (Timbalan Pengerusi, Tribunal Tuntutan Pengguna Malaysia, TTPM), dalam temu bual beliau dengan penulis, 26 Mei 2015.
} 
Tabung Haji atau wakil syarikat agensi pelancongan berdaftar yang menawarkan pakej haji serta umrah pada harga murah dan cepat. Namun, selepas mangsa membuat bayaran, pakej yang ditawarkan didapati tidak wujud. Malangnya, penipuan ini hanya disedari setelah mangsa sudah berada di lapangan terbang dan bersedia untuk memulakan perjalanan bagi menunaikan ibadah Haji atau Umrah (Ibid).

Pada masa ini, tidak ada sebarang bentuk kawalan berkaitan kepentingan pengguna dalam industri perkongsian masa. Peraturan yang ada ialah Akta Jualan Langsung dan Skim Anti Piramid 1993 yang tidak mempunyai peruntukan yang jelas untuk menyelesaikan masalah berkaitan industri ini. Akta ini hanya mengawal selia proses jualan langsung kepada pengguna. Terdapat banyak aspek dalam industri perkongsian masa yang perlu dikawal selia oleh Kementerian Perdagangan Dalam Negeri dan Hal Ehwal Pengguna (Ibid). Justeru itu, penyelidikan ini dilaksanakan bagi mengkaji dan menganalisis penyelesaian-penyelesaian yang komprehensif bagi mengatasi permasalahan yang dihadapi oleh ahli-ahli Skim Pelancongan Perkongsian Masa merangkap kepada pengguna skim ini.

Oleh sebab itu, para pengguna sendiri perlu mengambil langkah berjagajaga dalam membuat pilihan untuk menceburi sesuatu skim pelancongan. Sekiranya skim pelancongan yang ditawarkan itu jelas mempunyai syarat dan terma yang samar-samar dan diragui, maka pengguna seharusnya tidak tamak atau cuai untuk terus terpedaya untuk menceburkan diri ke dalam skim terbabit. Mohammad Nordin Ab. Rauf menjelaskan bahawa seberapa cantik dan sempurna suatu undang-undang yang digubal, ia tidak akan mampu untuk mengawal dan melindungi masyarakat sekiranya kita terus bersikap tamak dan cuai (Ibid).

\section{KESIMPULAN}

Kajian ini mendapati undang-undang sedia ada sudah cukup bagi menjadi garis panduan dalam merangka satu skim pelancongan dan memadai dalam mengawal dan melindungi masyarakat. Hal ini kerana peruntukan undang-undang yang ada adalah memadai untuk mendakwa pihak-pihak yang tidak telus sekaligus melindungi hak pihak-pihak yang berkontrak. Walau bagaimanapun, andaian bahawa penguatkuasaan dan pelaksanaan perlu dipertingkatkan lagi adalah kurang tepat. Hal ini kerana sistem penguatkuasaan dan pelaksanaan undangundang berkaitan skim pelancongan di Malaysia adalah sistematik dan mampu dijalankan dengan baik. Tinggal lagi, kesedaran masyarakat diperlukan untuk 
tampil ke hadapan bagi melaporkan kewujudan sebarang skim pelancongan yang mengandungi terma yang tidak jelas dan mengandungi unsur penipuan.

Secara keseluruhan, perlindungan pengguna ke atas skim pelancongan perlu melibatkan usaha dari segenap pihak termasuk Kerajaan Malaysia, para pengamal undang-undang dan masyarakat sendiri. Peruntukan undang-undang berkaitan skim pelancongan ini tidak mampu melindungi pengguna sekiranya ia tidak dikuatkuasakan dan dilaksanakan dengan baik. Walau bagaimanapun, masih terdapat ruang penambahbaikan dalam memastikan undang-undang itu terus diikuti oleh masyarakat dan mampu melindungi pengguna dari penindasan.

\section{RUJUKAN}

Ahmad Afiq Hasan \& Nuraisyah Chua Abdullah (2012). Tourism Industry Compensation Fund (TICF) in Malaysia: Some Legal and Policy Considerations. Petaling Jaya: CRC Press.

Asmah Haji Omar (1984). Bahasa Iklan Perniagaan: Satu Kajian Retorik. Kuala Lumpur: Dewan Bahasa dan Pustaka.

Berita Harian, "12 Syarikat Dibatal Lesen Kerana Kes Penipuan Umrah", Berita Harian Online, http://www.bharian.com.my/node/131665, dicapai 7 Mac 2016.

Bharat Raj Hazari \& Jian Jing Lin (2011). "Tourism, Terms of Trade and Welfare to the Poor," Journal of Scientific Research, 28-32.

Birshan Singh (2014). "Pendidikan Pengguna Untuk Hak-Hak dan Tanggungjawab Pengguna," Gabungan Persatuan-Persatuan Pengguna-Pengguna Malaysia.

Christof Pforr \& Peter J Hosie (2008). "Crisis Management in Tourism," Journal of Travel and Tourism Marketing, vol. 23, 2-4.

Jabatan Perangkaan Malaysia, "Penyiasatan pelancongan Domestik Malaysia", Laman Sesawang Jabatan Perangkaan Malaysia, https://www.dosm.gov. my/v1/index.php?r, dicapai 11 Mac 2015.

James Tunney (2010). "World Trade Law, Culture, Heritage and Tourism Towards a Holistic Conceptual Approach?," Journal of Current Issues in Tourism, vol. 7, 4-5.

John Swarbrooke \& Susan Horner (2007). Consumer Behaviour in Tourism. Second Edition. Netherland: Elsevier Ltd. 
Kementerian Perdagangan Dalam Negeri, Koperasi dan Kepenggunaan, "Tribunal Tuntutan Pengguna Malaysia", Laman Sesawang Kementerian Perdagangan Dalam Negeri, Koperasi dan Kepenggunaan Online, https://tpm.kpdnkk.gov.my/portal/index.php/my/, dicapai 26 Mei 2015.

Kurban Ünlüönen (2008). "Does Perceived Consumer Protection Differ in Tourism Industry by Nationality? A Case Study in Turkey," Journal of Hospitality \& Leisure Marketing, Vol. 10:1-2.

Mohamed Anwar Omar Din \& Zulayti Zakaria (2010). "Pelancongan Budaya di Malaysia: Membina Konsepnya," Jurnal Melayu, vol. 6.

Nuraisyah Chua Abdullah (2013). Rights and Liabilities of Holiday Makers and Holiday Providers. Petaling Jaya: International Law Book Services.

Pusat Khidmat Aduan Pengguna Nasional. "Info Pengguna-Time Share/ Kongsi Masa", Sinar Pusat Khidmat Aduan Pengguna Nasional Online, http://www.nccc.org.my/v2/index.php/time-share, dicapai 11 Mac 2015.

Rob Law (2009). "Internet and Tourism," Asia Pacific Journal of Tourism Research, vol. 14.

Sakina Shaik Ahmad Yusoff \& Azimon Abdul Aziz (2012). Mengenali Undang-Undang Kontrak Malaysia. Petaling Jaya: International Law Book Services.

Sakina Shaik Ahmad Yusoff, Azimon Abdul Aziz \& Suzanna Mohamed Isa (t.t.). "Undang-undang Kontrak Malaysia: Keterbatasan Pemakaian dalam Kontrak Pengguna," Jurnal Pengurusan, vol. 32.

Sinar Harian. "9 Kes Tipu Umrah Libat 14.1 Juta", Sinar Harian Online, http:/www.sinarharian.com.my/nasional/9-kes-tipu-umrah-libat-rm141-juta-1.291184, dicapai 7 Mac 2016.

Stepheni (2001). Tourism: A Modern Synthesis. London: Thompsom Learning. Thomas Frank (1997). The Conquest of Cool: Business Culture, Counterculture, and the Rise of Hip Consumerism. Chicago: The University of Chicago Press.

\section{Senarai Statut}

Akta Kontrak 1950 (Akta 136).

Akta Industri Pelancongan 1992 (Akta 482).

Akta Jualan Langsung dan Skim Anti Piramid 1993 (Akta 500).

Akta Perlindungan Pengguna 1999 (Akta 599). 


\section{Senarai Temu bual}

Aida Farihan M. Saleh @ Mohd Nawi (Pegawai Undang-Undang di Bahagian Undang-Undang KPDNKK), dalam temu bual beliau melalui panggilan telefon dengan penulis, 14 Mei 2015.

Mohammad Nordin Ab. Rauf (Timbalan Pengerusi, Tribunal Tuntutan Pengguna Malaysia, TTPM), dalam temu bual beliau dengan penulis, 26 Mei 2015.

Nurbaiti Abdul Karim (Pegawai Perhubungan, Right TIME Travel Sdn. Bhd.), dalam temu bual beliau dengan penulis, 23 Mac 2015. 